\title{
Cellulase Production from Rice Straw by Aspergillus flavus NRRL 5521
}

\author{
Hussein Azzaz Murad and Hossam El-Deen Hussein Azzaz \\ Department of Dairy Science, National Research Center, Dokki, Giza, Egypt
}

\begin{abstract}
The production of cellulase under the optimum fermentation conditions was studied. Non toxic Asperigllus flavus NRRL 5521 was grown as stand cultures in $500 \mathrm{~mL}$ conical flasks containing $50 \mathrm{~mL}$ Cellulose Powder Medium (CPM) for screening its ability for utilizing agricultural wastes as a carbon sources for cellulase production. The maximum production of cellulase by A. flavus NRRL 5521 reached $\left(0.11 \mathrm{IU} \mathrm{mL} \mathrm{min}^{-1}\right)$ was achieved at $10 \%$ rice straw, inoculum size of $7 \%, 48 \mathrm{~h}$ of incubation period, initial $\mathrm{pH}$ of growth medium 7.0 and yeast extract as a nitrogen sources at a concentration of $0.33 \mathrm{~g} \mathrm{~N} \mathrm{~L}^{-1}$. Scanning electron micrographs were taken to observe the hydrolytic impact of enzyme on the rice straw, it was evident from the photographs that the cells were separated after treatment as a result of cellulose hydrolysis.
\end{abstract}

Key words: Cellulase production, A. flavus, rice straw, yeast extract, banana wastes

Science International, 1 (4): 103-107, 2013

\section{INTRODUCTION}

Cellulose present in renewable lignocellulosic material is considered to be the most abundant organic substrate on earth for the production of glucose, for fuel and as chemical feed stock. Cellulose biodegradation by cellulases, produced by numerous microorganisms is very important in several agricultural and waste treatment processes $^{1,2,3}$.

Research on cellulase has progressed very rapidly in the past few decades, emphasis being on enzymatic hydrolysis of cellulose to glucose. The enzymatic hydrolysis of cellulose requires the use of cellulase [1,4-(1,3:1,4)-b-D-glucan glucanohydrolase, EC 3.2.1.4], a multiple enzyme system consisting of endo1,4,-b-Dglucanases [1,4-b-D-glucanases (CMCase, EC 3.2.1.4)], and exo 1,4,-b-D-glucanases $[1,4-\mathrm{b}-\mathrm{D}$ glucan cellobiohydrolase, FPA, EC 3.2.1.91] along with cellobiose (b-D-glucoside glucanohydrolase, EC 3.2.1.21)

Fungal genera like Aspergillus, Cladosporium, Fusarium, Geotrichum, Myrothecium, Paecilomyces, Penicillium and Trichoderma have received considerable study with respect to their cellulolytic enzymes capability. The development of microbial strains, media composition and process control have all contributed to achievements of high levels of extra cellular accumulation of cellulases for subsequent applications in industrial processes ${ }^{6}$.

The local production of such enzymes using locally available agricultural wastes which can serve as substrates

Corresponding Author: Hussein Azzaz Murad, Department of Dairy Science, National Research Center, P.O.Box 12622, Dokki, Giza, Egypt Tel: 20233068626 Fax: 20233370931 may therefore reduce the cost of importation and solve environmental problems, which are otherwise caused by their disposal.

This study was carried out to produce cellulase by A. flavus 5521 under the optimum conditions and evaluates the effects of resultant cellulase on rice straw degradation by using electronic microscope.

\section{MATERIALS AND METHODS}

Agricultural wastes substrates: Corn stalks, rice straw, wheat straw and banana wastes were collected after harvesting. The air-dried wastes were cut into $1-2 \mathrm{~cm}$ then dried at $60^{\circ} \mathrm{C}$ for $48 \mathrm{~h}$ in air-circulation oven and ground to powder then packed and stored in dry place at room temperature till use.

Microorganism, media and inoculum preparation: Asperigillus flavus NRRL 5521(non-aflatoxin producer strain) was used for screening its ability for utilizing cellulose as a main carbon source for production of cellulase; it was obtained from National Center for Agriculture Utilization Research, Microbial Genomics and Bioprocessing Research Unit, Department of Agriculture, Peoria, Illinois, USA. It was cultivated and maintained on potato dextrose agar medium (PDA). Malt medium containing malt extract $\left(30 \mathrm{~g} \mathrm{~L}^{-1}\right)$; yeast extract (5 $\mathrm{g} \mathrm{L}^{-1}$ ) was used for preparing the activated fungal inocula; Cellulose Powder Medium (CPM) recommended by Fadel $^{7}$ was used for growth and cellulase production. The medium has the following composition ( $\left.\mathrm{g} \mathrm{L}^{-1}\right) \mathrm{NaCl}, 6.0 ;\left(\mathrm{NH}_{4}\right)_{2} \mathrm{SO}_{4}$, $1.0 ; \mathrm{K}_{2} \mathrm{HPO}_{4}, 1.0 ; \mathrm{MgSO}_{4} .7 \mathrm{H}_{2} \mathrm{O}, 0.05 ; \mathrm{CaCl}_{2}, 0.1$; Yeast 
extract,0.5; peptone, 0.5; glucose, 4.0; cellulose powder, 2.0 and medium $\mathrm{pH}$ was adjusted to $\mathrm{pH}$ 6.0. Spores of Asperigillus flavus NRRL 5521were transferred from surface of the actively growing slants of (PDA) medium to $250 \mathrm{~mL}$ conical flasks each containing $50 \mathrm{~mL}$ of malt medium. After incubation on rotary shaker $(110 \mathrm{rpm})$ at $28+1^{\circ} \mathrm{C}$ for $48 \mathrm{~h}$, the grown cultures were employed as inocula for triplicate $500 \mathrm{~mL}$ conical flasks containing $50 \mathrm{~mL}$ of CPM at rate of $5 \%(\mathrm{v} / \mathrm{v})$ inoculum size.

Culture conditions affecting cellulase production: Cellulase production under variable conditions including carbon (substrate) source, inoculum size, incubation period, initial $\mathrm{pH}$ and nitrogen source were studied. Effect of substrate source was investigated through replacing cellulose powder in CPM by $10 \%$ (w/v) of different cellulolytic waste materials including corn stalks, rice straw, wheat straw and banana wastes. Effect of inoculum size ranged from 1 to $10 \%(\mathrm{v} / \mathrm{v})$ on cellulase activity was studied. The influence of incubation period was studied through determination of cellulase activities after 24, 48,72, 96 and $120 \mathrm{~h}$. Effect of the initial $\mathrm{pH}$ of growth medium was studied through adjusting the initial $\mathrm{pH}$ values in a range between 3 and 8 using either $\mathrm{NaOH}$ or $\mathrm{HCl} 0.1 \mathrm{~N}$. Effect of nitrogen source included the use of three inorganic salts (ammonium sulphate, ammonium chloride and sodium nitrate; and three organic sources (meat extract, yeast extract and peptone) were studied. Various nitrogen sources were used separately at an equivalent concentration of $0.33 \mathrm{~g} \mathrm{~N} \mathrm{~L}^{-1}$ media as recommended by Murad $^{8}$ these nitrogen sources replaced the original nitrogen present in the CPM. The level of an optimized parameter in an experiment was maintained in the subsequent studies.

Enzyme assay: The carboxymethyl-cellulase activity (CMC) for filtered and collected resultant enzyme was determined according to Mandels ${ }^{9}$.The reducing sugar liberated was determined by modified dinitrosalicyclic acid method (DNS) of Miller ${ }^{10}$. One cellulase unit is defined as the amount of enzyme that liberates reducing sugar at the rate of one $\mu \mathrm{mol} \mathrm{mL} \mathrm{min}^{-1} \mathrm{minder}^{-1}$ assay condition.

Enzymatic treatment of rice straw: Rice straw was collected by hand stripping, dried and then treated with laboratory produced crude enzyme extract (10 IU cellulase $/ 1 \mathrm{~g}$ DM of rice straw/1000 mL buffer acetate at $\mathrm{pH}$ 6.4) for $24 \mathrm{~h}$ at $40^{\circ} \mathrm{C}$ and $100 \mathrm{rpm}$ in a rotary shaker. The enzymatic untreated rice straw (control) was kept in flask at the same condition of treated rice straw. Finally, scanning electron micrographs of both treated and untreated rice straw fibers were taken to observe the effect of enzyme treatment.
Statistical analysis: The significance of the results was determined by the analysis of variance (ANOVA) evaluated by Duncan's multiple range tests ${ }^{11}$ (at 0.05 ), using IBM SPSS Statistics for Windows ${ }^{12}$.

\section{RESULTS AND DISCUSSION}

Effect of carbon source: As shown in Fig. 1 among of the available lignocellulosic substrates tested rice straw gave the highest cellulase production $(\mathrm{p}<0.05)$ with A. flavus NRRL $5521\left(0.046 \mathrm{IU} \mathrm{mL}^{-1}\right)$. Ojumu ${ }^{13}$ tested bagasse, corncob and sawdust as lignocellulosic substrates for production of cellulase enzyme using Aspergillus flavus; sawdust gave the best enzyme activity. Several studies of cellulase enzyme production by using different substrates and microorganisms have been found with different yields ${ }^{14,15,16}$. This is because various natural substrates are able to induce secreted enzymes which are favorable to degrade particular combinations of polysaccharides and chemicals found in the carbon source $^{17}$. Some environmental factors are also influenced the growth of organisms as well as maximum enzyme production including optimum temperature, $\mathrm{pH}$, salt concentration etc. ${ }^{18}$. The superiority of tested cellulolytic waste materials over carbon sources of CPM for cellulase production may be due to that cellulolytic waste materials can act as a source of carbon, nitrogen and minerals as well as growth factors. From the previous data, rice straw was selected as a sole carbon source for conducting further studies on cellulase production by A. flavus NRRL 5521.

Effect of inoculum size: The data shown in Fig. 2 indicated that the production of cellulase by $A$. flavus NRRL 5521 was increased significantly $(\mathrm{p}<0.05)$ by increasing inoculum size up to $7 \%\left(0.060 \mathrm{U} \mathrm{mL} \mathrm{m}^{-1}\right)$, respectively. Further increasing in inoculum size up to $10 \%$ led to decrease in cellulase production. Zhang ${ }^{19}$

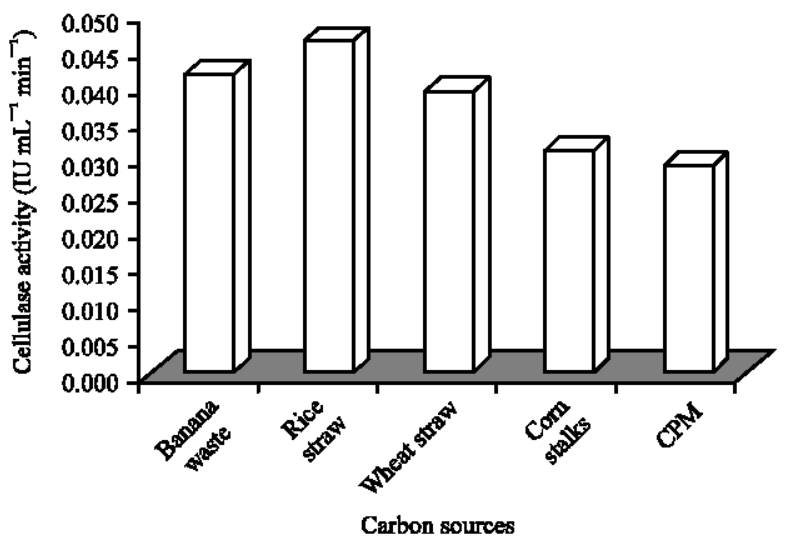

Fig. 1: Effect of carbon source on cellulase production by A. flavus NRRL 5521 


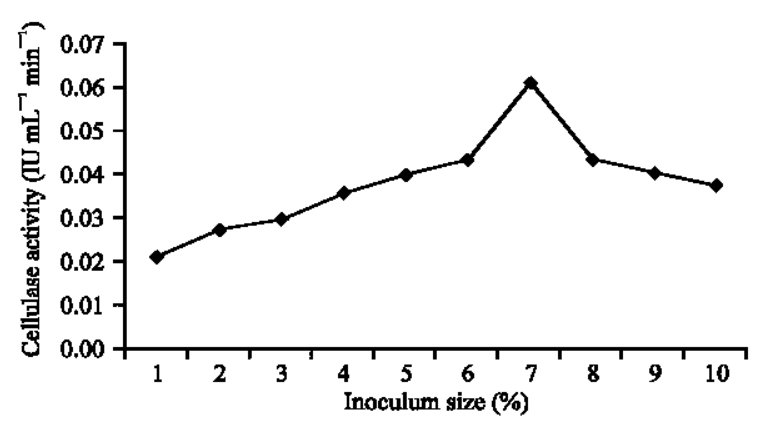

Fig. 2: Effect of inoculum size on cellulase production by A. flavus NRRL 5521

investigated the effect of inoculum size on cellulase synthesis by Trichoderma viride they reported that the impact of the amount of inoculant on cellulase production was small and 5\% inoculum was the most suitable, while, Omojasola ${ }^{20}$ found that amount of cellulase activity was decreased at inoculum sizes above 6 and $8 \%$ for pineapple peel and pineapple pulp fermentation by $A$. niger. The decrease in cellulase production with further increase in inoculum might be due to clumping of cells which could have reduced sugar and oxygen uptake rate and also, enzyme release ${ }^{20}$. From the previous data, $7 \%$ inoculum size was selected for conducting further studies on A. flavus NRRL 5521.

Effect of incubation period: The production of cellulase on CPM medium was monitored for a period of $120 \mathrm{~h}$ (Fig. 3). The highest cellulase activity ( $\mathrm{p}<0.05$ ) were recorded after $48 \mathrm{~h}$ of incubation with $A$. flavus NRRL 5521. Ojumu ${ }^{13}$ reported that A. flavus grown on sawdust, bagasse and corncob gave the highest cellulase activity at $12 \mathrm{~h}$ of fermentation. In our study the decrease in cellulase activity after more than $48 \mathrm{~h}$ might be due to denaturation of the enzyme, resulting from variation in $\mathrm{pH}$ during fermentation as reported by Krishna ${ }^{21}$, or may be due to cumulative effect of cellobiose, a dimer of glucose which is known to inhibit both endoglucanase and $\beta$-glucosidase ${ }^{22}$. Also, Hatakka ${ }^{23}$ suggested that delignification produces aromatic water-soluble products which can repress the cellulolytic action of the enzyme. From the previous data, $48 \mathrm{~h}$ incubation period was selected for conducting further studies on A. flavus NRRL 5521.

The effect of initial $\mathrm{pH}$ : The initial $\mathrm{pH}$ of the medium has a great effect on the growth of the organism, permeability membrane, as well as on the biosynthesis and stability of the enzymes ${ }^{24,25}$. As shown in Fig. 4. It is obvious that the initial $\mathrm{pH}$ of the medium has profound effect on cellulase production. The cellulase production by $A$. flavus NRRL 5521 in varying $\mathrm{pH}$ of CPM showed

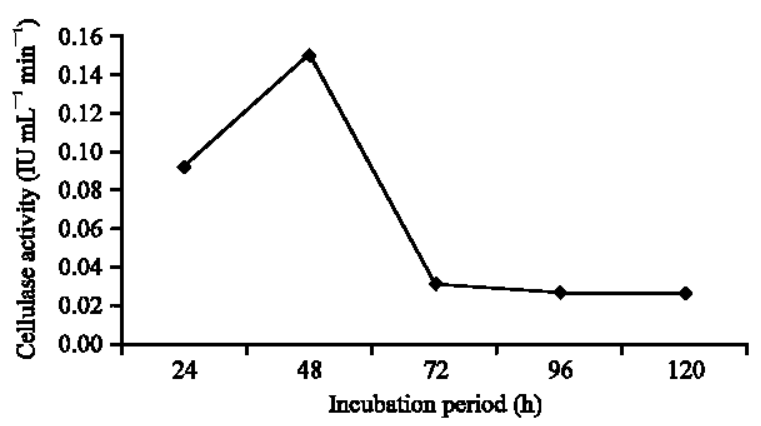

Fig. 3: Effect of incubation period on cellulase production by A. flavus NRRL 5521

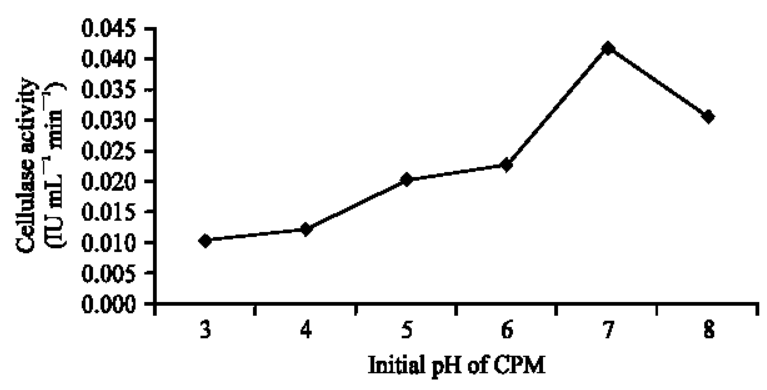

Fig. 4: Effect of initial $\mathrm{pH}$ on cellulase production by A. flavus NRRL 5521

highest values of cellulase activity $(\mathrm{p}<0.05)$ at $\mathrm{pH} 7.0$ $\left(0.042 \mathrm{IU} \mathrm{mL}^{-1}\right)$, more over when the $\mathrm{pH}$ level increased, the enzyme production was decreased. It was reported that optimal $\mathrm{pH}$ for CMCase from A. niger was found to be 6 to $7^{26}$. $\mathrm{Coral}^{27}$ observed that the enzyme activity has a broad $\mathrm{pH}$ range between 3 and 9 . These data suggest that the enzyme systems within the same species may vary, depending on the strain under study. Based on the results obtained, the initial $\mathrm{pH}$ of the medium was adjusted to $\mathrm{pH} 7.0$ for A. flavus NRRL 5521 in subsequent studies on CPM medium.

Effect of nitrogen source: The data shown in Fig. 5 revealed that among the 6 nitrogen sources tested, the yeast extract was found to be the best nitrogen source producing the highest level of cellulase activity $(\mathrm{p}<0.05)$ by A. flavus NRRL $5521\left(0.11 \mathrm{IU} \mathrm{mL} \mathrm{mL}^{-1}\right)$. This data indicating that the source of nitrogen should be organic for better results. Our results are in line with those of Enari $^{28}$ who reported that good cellulase production can be obtained with the organic nitrogen sources such as yeast extract and peptone; also Abou-Taleb ${ }^{29}$ reported that organic nitrogen sources were found to be more suitable for optimizing cellulase production by Bacillus alcalophilus S39 and Bacillus amyloliquefaciens $\mathrm{C} 23$ than inorganic sources while Xavier ${ }^{30}$ indicated that the source of nitrogen should be inorganic for better results. Differences in 


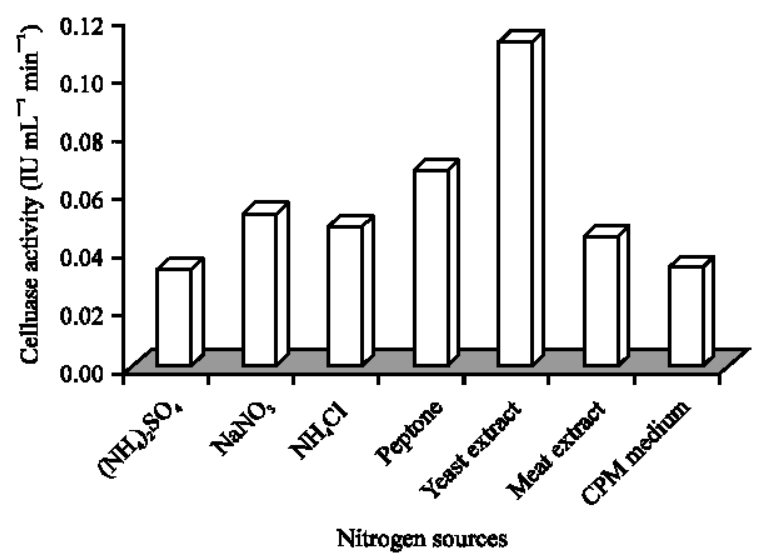

Fig. 5: Effect of nitrogen source on cellulase production by A. flavus NRRL 5521
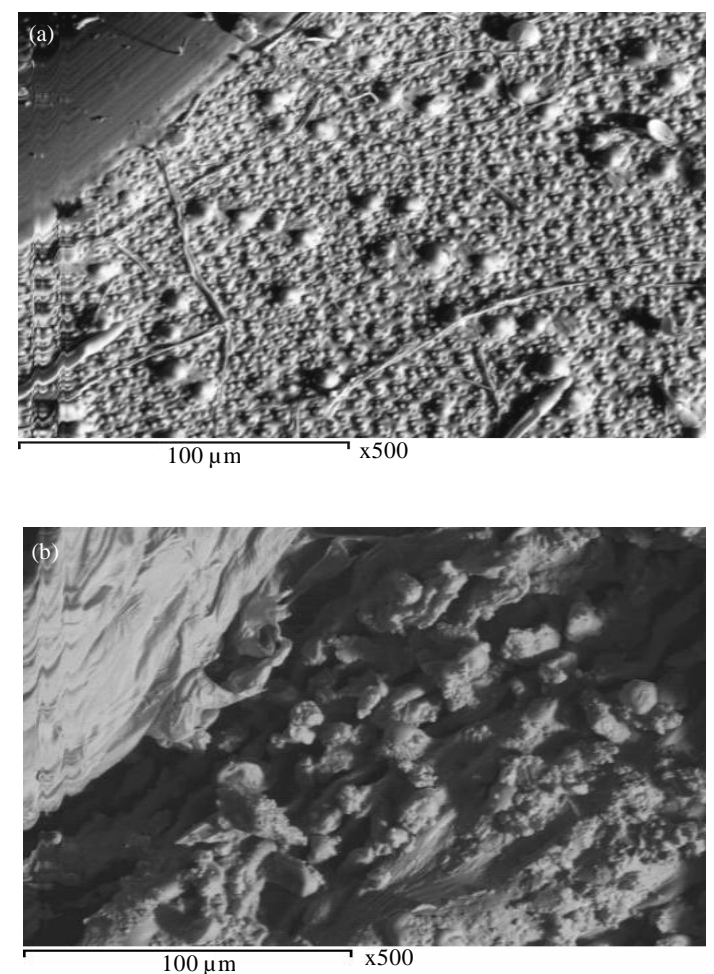

Fig. 6(a-b): Scanning electron micrographs of rice straw fibers. (A) Before and (b) after treatment with crude pectinase

titres of enzyme yields in different studies can be attributed to use of different materials as solid matrix, different cultural practices and different organisms ${ }^{31}$. From the previous data, yeast extract was selected for production of cellulase by A. flavus NRRL 5521.
Enzymatic treatment of rice straw fibers: In the present study hand stripped and dried rice straw fibers were treated with crude cellulase obtained from $A$. flavus NRRL 5521. Scanning electron micrographs were taken to observe the impact of enzyme on the fibers (Fig. 6). It was evident from the photographs that the cells were separated after treatment as a result of cellulose hydrolysis.

\section{CONCLUSION}

Cellulase from A. flavus NRRL 5521 was successfully produced under the optimum conditions using rice straw as substrate. This may represent a promising approach foe cellulose biodegradation of agricultural wastes to be used in glucose, fuel production and as chemical feed stock and overcoming its disposal problems.

\section{REFERENCES}

1. Angenent, L.T., K. Karim, M.H. Al-Dahlan, B.A. Wrenn and R. Domiquez-Espinosa, 2004. Production of bioenergy and biochemicals from industrial and agricultural wastewater. Trends Biotechnol., 22: 477-485.

2. Das, H. and S.K. Singh, 2004. Useful byproducts from cellulosic wastes of agriculture and food industry- a critical appraisal. Crit. Rev. Food. Sci. Nutr., 44: 77-89.

3. Haight, M., 2005. Assessing the environmental burdens of anaerobic digestion in comparison to alternative options for managing the biodegradable fraction of municipal solid wastes. Water. Sci. Technolnol., 52: 553-559.

4. Bhat, M.K., 2000. Cellulases and related enzymes in biotechnology. Biotechnol. Adv., 18: 355-383. 
5. Lynd, L.R., P.J. Weimer, W.H. van Zyl and I.S. Pretorius, 2002. Microbial cellulose utilization: Fundamentals and biotechnology. Microbiol. Mol. Biol. Rev., 66: 506-577.

6. Ghose, T.K., 1987. Measurement of cellulase activities. Pure Applied Chem., 59: 257-268.

7. Fadel, M. and M.S. Foda, 1993. Production of fungal cellulases under static conditions for saccharification of lignocellulosic wastes in Egypt. Egypt. J. Microbiol., 28: 289-301.

8. Murad, H.A., 1998. Utilization of ultrafiltration permeate for production of B. galactosidase from Lactobacillus bulgaricus. Milchwissenschaft, 53: 273-276.

9. Mandels, M., L. Hontz and J. Nystrom, 1974. Enzymatic hydrolysis of waste cellulose. Biotechnol. Bioeng., 16: 1471-1493.

10. Miller, G.L., 1972. Use of dinitrosalicyclic acid reagent for determination of reducing sugar. Biotechnol. Bioeng., 5: 193-219.

11. Duncan, D.B., 1955. Multiple range and multiple F tests. Biometrics, 11: 1-42.

12. IBM, 2011. IBM SPSS Statistics for Windows, Version 20.0. IBM Corp., Armonk, New York.

13. Ojumu, T., V. Solomon, O. Bamidele, E. Betiku, S.K. Layokun and B. Amigun, 2003. Cellulase production by Aspergillus flavus Linn. isolate NSPR 101 fermented in sawdust, bagasse and corncob. Afr. J. Biotechnol., 2: 150-152.

14. Mandels, M. and E.T. Reese, 1985. Fungal cellulase and microbial decomposition of cellulosic fibres. Dev. Ind. Microbiol., 5: 5-20.

15. Zhu, Y.S., Y.Q. Wu, W. Chen, C. Tan and J.H. Gao et al., 1982. Induction and regulation of cellulase synthesis in Trichoderma pseudokoningii mutant EA3-867 and $\mathrm{N}_{2}-78$. Enzyme. Microbiol. Technol., 4: 3-12.

16. Lakshmikant, K. and S.N. Mathur, 1990. Cellulotytic activities of Chaetomium globosum on different cellulosic substrates. World. J. Microbiol. Biotechnol., 6: 23-26.

17. Alam, Z.M., S.A. Muyibi and R. Wahid, 2008. Statistical optimization of process conditions for cellulase production by liquid state bioconversion of domestic wastewater sludge. Bioresour. Technol., 99: 4709-4716.

18. Immanuel, G., R. Dhanusa, P. Prema and A. Palavesam, 2006. Effect of different growth parameters on endoglucanase enzyme activity by bacteria isolated from coir retting effluents of estuarine environment. Int. J. Environ. Sci. Tech., 3: 25-34.
19. Zhang, L.R., G. Zu, K. Shi, L. Zhang and K.C. Zhang, 2001. Cellulase production by solid state fermentation of distillers wheat. Microbiol. Biotech., 20: 27-32.

20. Omojasola, P.F., O.P. Jilani and S.A. Ibiyemi, 2008. Cellulase production by some fungi cultured on pineapple waste. Nature Sci., 6: 64-69.

21. Krishna, C., 1999. Production of bacterial cellulases by solid substrate bioprocessing of banana wastes. Bioresour. Technol., 69: 231-239.

22. Howell, J.A. and M. Mangat, 1978. Enzyme deactivation during cellulose hydrolysis. Biotechnol. Bioeng., 20: 847-863.

23. Hattaka, A.I., 1983. Biological pretreatment of lignocellulose. Applied Microbiol. Biotechnol., 18: 350-357.

24. Shoichi, T., K. Xoighi and S. Hiroshi, 1985. Cellulase production by $P$. purpurogenum. J. Ferment. Technol., 62: 127-127.

25. Poorna, C.A. and P. Prema, 2007. Production of cellulase free endoxylanase from novel alkalophilic thermotolerent Bacillus pumillus by solid state fermentation and its application in wastepaper recycling. Bioresour. Tech., 98: 485-490.

26. Parry, J.B., J.C. Stewart and J. Heptinstall, 1983. Purification on the major endoglucanase from Aspergillus fumigatus Frecius. Biochem. J., 213: 437-444.

27. Coral, G.K., B. Arikan, M.N. Unaldi and H. Guvenmez, 2002. Some properties of crude carboxymethyl cellulase of Aspergillus niger Z10 Wild-Type Strain. Turk. J. Biol., 26: 209-213.

28. Enari, T.M. and P. Markenan, 1977. Production of cellulolytic enzymes by fungi. Adv. Biochem. Eng., 5: $1-23$.

29. Abou-Taleb, K.A.A., W.A. Mashhoor, S.A. Nasr, M.S. Sharaf and H.H.M. Abdel-Azeem, 2009. Nutritional and environmental factors affecting cellulase production by two strains of Cellulolytic bacilli. Aust. J. Basic Applied Sci., 3: 2429-2436.

30. Xavier, S. and B.K. Lonsane, 1994. Factors influencing fungal degradation of total soluble carbohydrates in sugarcane-pressmud under solid state fermentation. Proc. Biochem., 29: 295-301.

31. Chandra, M.S., B. Viswanath and B.R. Reddy, 2007. Cellulolytic enzymes on lignocellulosic substrates in solid state fermentation by Aspergillus niger. Indian J. Microbiol., 47: 323-328. 